Ferrari, B. A., B. M. Shamblin, R. B. Chandler, H. R. Tumas, S. Hache, L. Reitsma, and C. J. Nairn. 2018. Canada Warbler (Cardellina canadensis): novel molecular markers and a preliminary analysis of genetic diversity and structure. Avian Conservation and Ecology 13(1):8. https://doi. org/10.5751/ACE-01176-130108

Copyright (C) 2018 by the author(s). Published here under license by the Resilience Alliance.

Short Communication

\title{
Canada Warbler (Cardellina canadensis): novel molecular markers and a preliminary analysis of genetic diversity and structure
}

\author{
Brittney A. Ferrari ${ }^{1}$, Brian M. Shamblin ${ }^{1}$, Richard B. Chandler ${ }^{1}$, Hayley R. Tumas ${ }^{1}$, Samuel Hache ${ }^{2}$ Leonard Reitsma $^{3}$ \\ and Campbell J. Nairn ${ }^{1}$ \\ ${ }^{1}$ University of Georgia, Warnell School of Forestry and Natural Resources, ${ }^{2}$ Canadian Wildlife Service, Environment and Climate \\ Change Canada, Yellowknife, NT, Canada, ${ }^{3}$ Plymouth State University, Biological Sciences
}

\begin{abstract}
The effects of predicted declines and potential loss of individual populations on species-level genetic diversity is unclear. A number of taxa, including the Canada Warbler (Cardellina canadensis), share wide-ranging geographic distributions in North American boreal forests with trailing-edge populations extending into the southern Appalachian Mountains. Trailing-edge populations in the southern portion of a species' ranges often harbor high levels of genetic diversity and unique genetic variants, and may be at risk of extinction from climate change. Climate change and other anthropogenic factors are causing declines in the Canada Warbler's southern trailing-edge populations, and with no genetic studies to date, the effect on species-level genetic diversity is uncertain. Speciesspecific microsatellite markers for the Canada Warbler were developed and validated using samples from three populations, including a southern trailing-edge population, to investigate their utility for intraspecific population studies. Eight of the microsatellite markers were informative for assessing genetic diversity and preliminary analysis suggests that they have potential for characterizing intraspecific neutral genetic diversity and structure among Canada Warbler populations.
\end{abstract}

\section{La Paruline du Canada (Cardellina canadensis) : nouveaux marqueurs moléculaires et analyse préliminaire de la diversité et de la structure génétique}

RÉSUMÉ. Les effets des baisses prédites et des pertes potentielles de certaines populations sur la diversité génétique à l'échelle de l'espèce sont incertains. Un grand nombre de taxons, dont la Paruline du Canada (Cardellina canadensis), partagent des répartitions géographiques très vastes dans les forêts boréales nord-américaines avec certaines populations s'étendant à la marge de l'aire de répartition jusque dans le sud des Appalaches. Ces populations situées à la limite sud de l'aire d'une espèce présentent souvent un degré élevé de diversité génétique et des variations génétiques uniques, et pourraient être à risque d'extinction à cause des changements climatiques. Les changements climatiques et d'autres facteurs d'origine humaine sont responsables de baisses dans les populations situées à la limite sud chez la Paruline du Canada, et en l'absence d'études génétiques jusqu'à présent, l'effet de la diversité génétique à l'échelle de l'espèce est incertain. Des marqueurs microsatellites spécifiques à la Paruline du Canada ont été élaborés et validés au moyen d'échantillons provenant de trois populations, y compris une population située à la limite sud, afin d'examiner leur utilité pour des études populationnelles intraspécifiques. Huit des marqueurs microsatellites se sont avérés instructifs pour évaluer la diversité génétique, et une analyse préliminaire indique qu'ils ont du potentiel pour caractériser la diversité et la structure génétique neutre intraspécifique parmi les populations de Paruline du Canada.

Key Words: Canada Warbler; Cardellina canadensis; climate change; genetic diversity; genetic structure; southern trailing-edge population

\section{INTRODUCTION}

In North America, the ranges of many species are shifting toward higher latitudes and upward in elevation in response to recent climate change (Parmesan 2006, Zuckerberg et al. 2009, Ralston and Kirchman 2013, Mason et al. 2015). Populations unable to respond to rapid environmental changes through range shifts or adaptation will be at risk of extinction, which may cause an overall loss of genetic diversity species-wide (Hughes et al. 1997, Davis and Shaw 2001, Dawson et al. 2011, Frankham 2005, McInerny et al. 2009, Pauls et al. 2013). Furthermore, loss of genetic diversity will likely be underestimated if cryptic diversity and intraspecific genetic variation are not considered (Pauls et al.
2013). Populations at the leading-edge of a range expansion may have relatively low levels of genetic diversity due to founder effects (Cobben et al. 2011, Arenas et al. 2012). Differences in genetic diversity between central and peripheral populations may be slight (Eckert et al. 2008), and in some cases, regional genetic diversity of trailing-edge populations can be high, especially when these populations exist near glacial refugia that were relatively stable during Pleistocene climate oscillations (Tzedakis et al. 2002, Vucetich and Waite 2003, Hewitt 2004, Eckert et al. 2008). Furthermore, decreased gene flow among peripheral populations can lead to pronounced genetic structure (Bohonak 1999), and trailing-edge populations may harbor unique alleles not found in 
other regions of the range (Petit et al. 2003, Hewitt 2004, Provan and Maggs 2012). The possibility that some trailing-edge populations were diverging from populations at higher latitudes prior to recent environmental change (Hewitt 1996, Hampe and Petit 2005, Parisod and Joost 2010) has led to calls for their recognition as distinct ecological and evolutionary units (Crandall et al. 2000, Fraser and Bernatchez 2001).

The Canada Warbler (Cardellina canadensis) is a NeotropicalNearctic migratory species of conservation concern that, according to the North American Breeding Bird Survey (BBS), has been declining at a rate of $2.3 \%$ per year since 1966 (Sauer et al. 2014). Although BBS data are not sufficient for reliably estimating historic trends of peripheral Canada Warbler populations in the northern boreal or southern Appalachian Mountain regions, species distribution models predict widespread population declines near the southern edge of the breeding range (Matthews et al. 2004, Sauer et al. 2014). Population declines and model projections have prompted organizations such as the North American Bird Conservation Initiative, Partners in Flight, and the Northeast Endangered Species and Wildlife Diversity Technical Committee to designate Canada Warblers as high priority for research and conservation (Reitsma et al. 2010, Stralberg et al. 2015, 2017). In Canada, this species is listed as Threatened under the Species at Risk Act (S.C. 2002, c.29; Environment Canada 2016). The National Audubon Society has classified Canada Warbler as one of 188 North American bird species that is expected to lose more than $50 \%$ of its geographic range by 2080 because of climate change (Langham et al. 2015).

The breeding range of the Canada Warbler extends across the southern boreal region of Canada into the northeastern United States, including the Great Lakes region and Appalachian Mountains into northeastern Georgia (Reitsma et al. 2010). Southern Appalachian populations are patchily distributed and restricted to habitats above $1000 \mathrm{~m}$ elevation (COSEWIC 2008, Reitsma et al. 2010). Canada Warblers utilize various habitats throughout their range, but are most common in moist, mixed coniferous-deciduous forests (Reitsma et al. 2010, Haché et al. 2014, Ball et al. 2016). As ground nesters, they are dependent on complex forest structure, especially dense understory vegetation (Hallworth et al. 2008, Goodnow and Reitsma 2011, Becker et al. 2012). Adult Canada Warblers display high breeding site fidelity (Hallworth et al. 2008), which has been documented as a contributor to limited gene flow and strong population structure in other songbird species (Temple et al. 2006, Coulon et al. 2008, Walsh et al. 2012). The extent of natal dispersal is largely unknown, although it can be as short as $500 \mathrm{~m}$ in North Carolina and New Hampshire (RBC and LRR, unpublished data).

No population studies examining genetic diversity and structure have been conducted for the Canada Warbler and no molecular markers for the species have been reported. Development of neutral molecular markers for the species will facilitate studies examining genetic diversity and connectivity across the Canada Warbler's range. It is unclear how the loss of peripheral populations might impact species-level genetic diversity, therefore, characterizing genetic diversity and distribution for the species is needed to inform conservation and management strategies. To address this need, we developed novel speciesspecific microsatellite markers for Canada Warbler and conducted a preliminary analysis to evaluate their utility for intraspecies population studies. We compared a leading- and a trailing-edge breeding population to a population located within the central portion of the species' breeding range. We hypothesized that southern populations would have high levels of genetic diversity because they occur near glacial refugia in the southern Appalachian Mountains and that the three populations would be genetically distinct because of geographic distances between them.

\section{METHODS}

\section{Sample collection}

Rectrices were collected from Canada Warblers breeding in three study areas: the United States Department of Agriculture (USDA) Coweeta Hydrologic Laboratory in Otto North Carolina, U.S. (NC, $\mathrm{n}=72$ ), Canaan, New Hampshire, U.S. (NH, $\mathrm{n}=57)$, and Fort Liard in the Northwest Territories, Canada (NWT, $\mathrm{n}=40$ ) during the 2014 and 2015 breeding seasons (Fig. 1). Pairwise geographic distances between Coweeta NC-Canaan NH, Coweeta NC-Fort Liard NWT, and Canaan NH-Fort Liard NWT are 1371 km, 3997 $\mathrm{km}$, and $3856 \mathrm{~km}$, respectively. Individuals were caught by mist net and were banded with United States Geological Survey (USGS) aluminum bands. At the NC site, approximately $100 \mu \mathrm{L}$ of blood was collected from the brachial vein and stored on Flinders Technology Associates (FTA ${ }^{\mathrm{TM}}$ ) cards or in lysis buffer. Samples placed on $\mathrm{FTA}^{\mathrm{TM}}$ cards were allowed to dry and stored at $-20^{\circ} \mathrm{C}$. Samples in lysis buffer were stored at room temperature. Two rectrices were obtained from each individual and placed in small envelopes, which were stored at room temperature or $-20{ }^{\circ} \mathrm{C}$. Samples collected in $\mathrm{NH}$ and Canada were subsequently transferred to $95 \%$ ethanol for preservation and transport.

Fig. 1. Distribution map of the breeding and migratory range for Canada Warblers (Cardellina canadensis). Sample collection sites are indicated on map with lettered circles: (A) Coweeta, North Carolina, USA; (B) Canaan, New Hampshire, USA; (C) Fort Liard, Northwest Territories, Canada. (Map from The Birds of North America https://birdsna.org; used with permission)

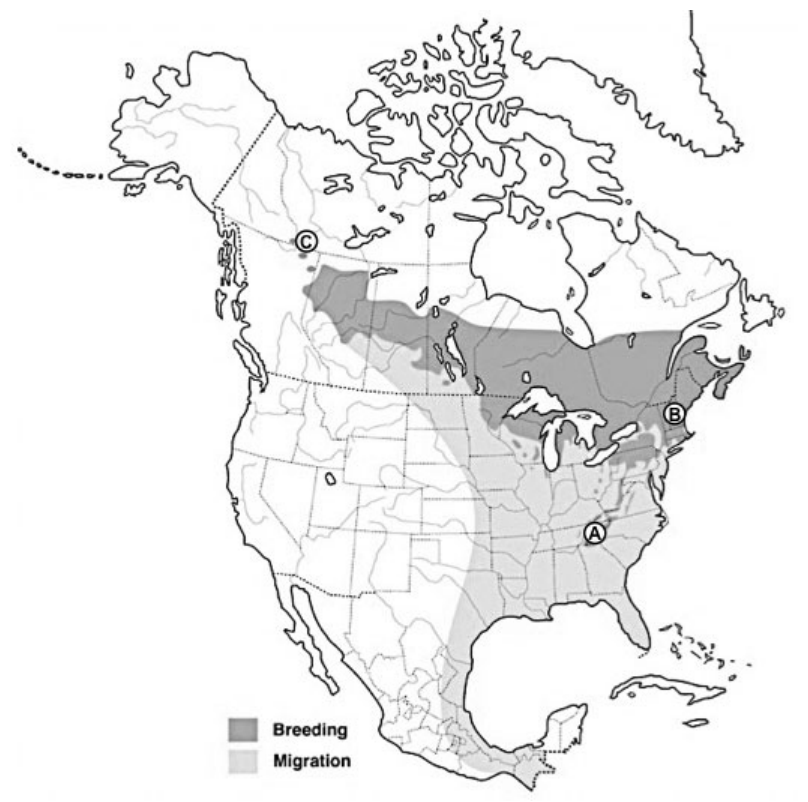


Table 1. Characterization of microsatellite markers developed for Canada Warblers (Cardellina canadensis) tested on samples from a single population in Coweta, North Carolina. N, number of individuals genotyped at each locus; $\mathrm{k}$, number of alleles at each locus; $\mathrm{H}_{\mathrm{O}}$, observed heterozygosity; $\mathrm{H}_{\mathrm{E}}$, expected heterozygosity; and $\mathrm{P}_{\mathrm{HW}}$, probability that genotype proportions conform to Hardy-Weinberg Proportions. GenBank accession numbers are listed for each microsatellite locus sequence.

\begin{tabular}{|c|c|c|c|c|c|c|c|c|c|}
\hline Locus & Primer Sequence & Motif & $\mathrm{N}$ & $\mathrm{k}$ & Size range (bp) & $\mathrm{H}_{0}$ & $\mathrm{H}_{\mathrm{F}}$ & $\mathrm{P}_{\mathrm{HW}}$ & GenBank \\
\hline$\overline{\text { CAWA05 }}$ & $\begin{array}{l}\text { F: }{ }^{\mathrm{a}} \text { GGTCCCTCTCAGATGTGTCC } \\
\text { R: }{ }^{\mathrm{b}} \text { AGCCCTCTGATGTCTTCTCG }\end{array}$ & $\left(\right.$ ATATC $^{11}$ & 71 & 9 & $232-272$ & 0.732 & 0.768 & 0.6571 & KY924652 \\
\hline CAWA11 & $\begin{array}{l}\text { F: }{ }^{a} \text { ATAAACTCCGTGGCTGCTG } \\
\text { R: }{ }^{\mathrm{b} C C T C T C T G C C A C C T T T C C}\end{array}$ & $(\mathrm{AACAT})^{16}$ & 70 & 10 & $152-202$ & 0.714 & 0.867 & $<0.0001$ & KY924653 \\
\hline CAWA13 & $\begin{array}{l}\text { F: }{ }^{a} \text { CCTCAAGAGCCAGAAAGC } \\
\text { R: }{ }^{b} \text { GGCCTAGAGACAGCTGTTG }\end{array}$ & $(\mathrm{ATGCC})^{17}$ & 72 & 14 & $389-454$ & 0.917 & 0.898 & 0.7964 & KY924654 \\
\hline CAWA20 & $\begin{array}{l}\text { F: }{ }^{a} \text { ACCCTGTACCTTTCTCCCG } \\
\text { R: }{ }^{\mathrm{b}} \text { AGCTGTTACTTTGGCGAGTG }\end{array}$ & $(\mathrm{AGAT})^{14}$ & 71 & 8 & $375-403$ & 0.803 & 0.813 & 0.8833 & KY924655 \\
\hline CAWA25 & $\begin{array}{l}\text { F: }{ }^{a} \text { ACTTGCTTGTCACCTTGC } \\
\text { R: }{ }^{\mathrm{b}} \text { ACCCTAAAGCACTCTCGAGC }\end{array}$ & $(\mathrm{ATCC})^{17}$ & 71 & 11 & $112-196$ & 0.648 & 0.835 & $<0.0001$ & KY924656 \\
\hline${ }^{\dagger}$ CAWA28 & $\begin{array}{l}\text { F: }{ }^{\mathrm{a}} \text { GGAACACATGCTCTGCCTC } \\
\text { R: }{ }^{\mathrm{b}} \text { AAACGTCCTGCTTTCTGTCG }\end{array}$ & $(\mathrm{AAAG})^{25}$ & 71 & 32 & $264-484$ & 0.915 & 0.956 & $<0.0001$ & KY924657 \\
\hline CAWA29 & $\begin{array}{l}\text { F: }{ }^{c} \text { GGACCTCTGAGCAATCTGG } \\
\text { R: }{ }^{b} \text { CTTTCCACAGCCCGTTGTAC }\end{array}$ & $(\text { AAATAG })^{11}$ & 70 & 23 & $435-546$ & 0.871 & 0.935 & 0.2310 & KY924658 \\
\hline CAWA30 & $\begin{array}{l}\text { F: }{ }^{c} \text { GGTTTCACACACATCCCTCC } \\
\text { R: }{ }^{b} \text { GGATGGACAGAGGGATGAC }\end{array}$ & $(\mathrm{AAAGAG})^{25}$ & 69 & 29 & $285-450$ & 0.942 & 0.945 & 0.9843 & KY924659 \\
\hline CAWA33 & $\begin{array}{l}\text { F: }{ }^{\mathrm{C}} \text { TCTTTCTGCCCTCCTCTGG } \\
\text { R: }{ }^{\mathrm{b}} \text { AAGATGGAACCAGGCCTCAG }\end{array}$ & $(\mathrm{AAGAG})^{11}$ & 72 & 12 & $214-274$ & 0.875 & 0.855 & 0.8055 & KY924660 \\
\hline${ }^{\dagger}$ CAWA37 & $\begin{array}{l}\text { F: }{ }^{\mathrm{c}} \text { GCTCCCATCTCTGCCATAG } \\
\mathrm{R}:{ }^{\mathrm{b}} \mathrm{CCTTCAATGTCACCTGTGCC} \\
\end{array}$ & $(\mathrm{AGATG})^{15}$ & 72 & 19 & $290-456$ & 0.75 & 0.913 & $<0.0001$ & KY924661 \\
\hline $\begin{array}{l}{ }^{\mathrm{a}} \text { CAG Tag } \\
{ }^{\mathrm{b}} \text { GTTT Tas } \\
{ }^{\mathrm{c}} \text { M13 Tag }( \\
{ }^{\dagger} \text { Markers tl }\end{array}$ & $\begin{array}{l}\text { CAGTCGGGCGTCATCA) } \\
\text { (GTTT) } \\
\text { GGAAACAGCTATGACCAT) } \\
\text { at were removed prior to analyses becaus }\end{array}$ & gh null allele & & & & & & & \\
\hline
\end{tabular}

\section{DNA extraction and analysis}

Total genomic DNA was isolated from individual samples of either $10 \mu \mathrm{L}$ of blood or single feathers using the DNEasy Blood and Tissue ${ }^{\circledR}$ kit (Qiagen). Feather samples were macerated prior to digestion. Individual DNA samples were genotyped using the 10 locus-specific primer pairs. Amplification reaction conditions, thermal cycling parameters, fragment analyses, and allele scoring were conducted as previously described in Tumas et al. (2017).

\section{Primer development}

Novel microsatellite markers were developed for population genetic studies of Canada Warbler. Genomic DNA was isolated from a blood sample, obtained from a Canada Warbler captured in NC, using a DNEasy Blood and Tissue ${ }^{\circledR}$ kit (Qiagen). Total genomic DNA was used for library preparation using the Kapa Biosystems ${ }^{\circledR}$ KAPA LTP Library Preparation Kit for Illumina ${ }^{\circledR}$ platforms. Paired-end sequences were analyzed using the Illumina ${ }^{\circledR}$ NextSeq sequencing system. Paired reads were assembled using Geneious 8.1.6 (Kearse et al. 2012) and sequences over $150 \mathrm{bp}$ in length were extracted and queried for microsatellite loci using MSATCOMMANDER (Faircloth 2008). Of the 3300 microsatellites identified, 1100 included unique sequences surrounding the repeats with sufficient length for primer design. Forty-eight primers pairs were selected using repeat length, motif, number of repeating units and primer pair penalty. Primers were tagged as noted (Table 1). A M13, CAG, or GTTT tag was added to the $5^{\prime}$ terminus of locus-specific primers and amplification reactions carried out as described in Tumas et al. (2017). The 48 primer pairs were screened for amplification consistency and polymorphism in 30 Canada Warblers captured at the NC study site. Loci were not tested for sex linkage and all loci that produced inconsistent amplification or null alleles were excluded. Ten primer pairs amplified consistently in these samples and were subsequently used to genotype samples from the three populations (Table 1).

\section{Genetic diversity}

Allelic data were scored using GeneMapper ${ }^{\circledR} 5.0$ (Applied Biosystems) and formatted for analysis using GMCONVERT (Faircloth 2006). CERVUS 3.0 (Kalinowski et al. 2007) was used to calculate mean number of alleles per locus $(\mathrm{k})$, observed heterozygosity $\left(\mathrm{H}_{\mathrm{O}}\right)$, expected heterozygosity $\left(\mathrm{H}_{\mathrm{E}}\right)$, and deviations from Hardy-Weinberg Proportions $\left(\mathrm{P}_{\mathrm{HW}}\right)$. Linkage disequilibrium (LD) was calculated using GENEPOP (Raymond and Rousset 1995; Table 1). Arlequin (Excoffier et al. 2005) was used to calculate $\mathrm{H}_{\mathrm{O}}, \mathrm{H}_{\mathrm{E}}$, and $\mathrm{k}$ for each study area. Number of private alleles was calculated in $\mathrm{R}$ using the poppr package (Kamvar et al. 2014, R Core Team 2016). Allelic richness $\left(A_{R}\right)$ with rarefaction to the minimum population sample size (n) was calculated in $\mathrm{R}$ using the divBasic function in the "diveRsity" package (Keenan et al. 2013, R Core Team 2016). Significant differences in observed heterozygosity and allelic richness were tested between pairs of the three populations using a two sample $\mathrm{t}$-test across locus values for each metric in $\mathrm{R}$.

\section{Population differentiation}

Estimates of pairwise $\mathrm{F}_{\mathrm{ST}}$ values were calculated using Arlequin (Excoffier et al. 2005). STRUCTURE 2.2 (Pritchard et al. 2000) was used to estimate the number of genetically distinct clusters. Both the admixture and the no admixture model were implemented in STRUCTURE $(250,000$ burnin, 250,000 
additional MCMC iterations) with correlated allele frequencies, using sampling locations as a prior (locprior) as well as without sampling locations as a prior, and otherwise default settings. We ran 20 iterations for each hypothesized number of genetic clusters (K) ranging from 1 to 6 . The optimal $\mathrm{K}$ was evaluated using two methods, the Evanno method (Evanno et al. 2005) and the lnlikelihood method as described in Rosenberg et al. (2001) using the average probability per value of $K$. STRUCTURE HARVESTER (Earl and vonHoldt 2012) was used to evaluate the optimal $\mathrm{K}$ according to the method described in Evanno et al. (2005).

\section{RESULTS}

\section{Primer development}

Forty-eight primers pairs were tested for amplification using 30 Canada Warbler samples from the NC study site. Ten primer pairs consistently amplified the respective locus. Two markers (CAWA28 and CAWA37) of the 10 microsatellite markers validated in this study produced high null allele frequencies that could not be resolved with subsequent regenotyping. These two loci were excluded from subsequent analyses (Table 1).

\section{Genetic diversity}

The number of alleles per locus for the 169 genotyped individuals ranged from 8 to 32 . Overall, populations had an average observed heterozygosity $\left(\mathrm{H}_{\mathrm{O}}\right)$ of 0.80 , and an average allelic diversity $(\mathrm{k})$ of 17.5 (Table 2). Observed heterozygosity was similar for the three populations $(\mathrm{NC}=0.80, \mathrm{NH}=0.80, \mathrm{NWT}=0.78)$. Allelic richness was highest in the $\mathrm{NH}$ population (13.6), intermediate in the NC population (12.8), and lowest in the NWT population (11.6). Observed heterozygosity and allelic richness were not significantly different between any pair of populations based on a two sample t-test $(p>0.05)$. The total number of private alleles was 27 , with 16 alleles in the NH population, 10 identified in the NC population, and one in the NWT population.

Table 2. Number of individuals genotyped $(\mathrm{N})$, observed heterozygosity $\left(\mathrm{H}_{\mathrm{O}}\right)$, expected heterozygosity $\left(\mathrm{H}_{\mathrm{E}}\right)$, mean number of alleles per locus $(\mathrm{k})$, and private alleles.

\begin{tabular}{lcccccc}
\hline \hline $\begin{array}{l}\text { Popula- } \\
\text { tion }\end{array}$ & $\mathrm{N}$ & $\mathrm{H}_{\mathrm{O}}$ & $\mathrm{H}_{\mathrm{E}}$ & $\mathrm{k}$ & $\mathrm{A}_{\mathrm{R}}$ & $\begin{array}{c}\text { Private } \\
\text { Alleles }\end{array}$ \\
\hline $\mathrm{NC}$ & 72 & 0.80 & 0.86 & 14.5 & 12.8 & 10 \\
$\mathrm{NH}$ & 57 & 0.80 & 0.87 & 15.1 & 13.6 & 16 \\
$\mathrm{NWT}$ & 40 & 0.78 & 0.87 & 12.3 & 11.6 & 1 \\
Overall & 169 & 0.80 & 0.87 & 17.5 & $\mathrm{NA}$ & 27 \\
\hline
\end{tabular}

\section{Population differentiation}

Pairwise estimates of $\mathrm{F}_{\mathrm{ST}}$ indicated that the NC population was significantly different from $\mathrm{NH}$ and $\mathrm{NWT}\left(\mathrm{F}_{\mathrm{ST}}=0.008, \mathrm{p}<0.0001\right.$ for both comparisons), but the NH and NWT populations were not significantly different $\left(\mathrm{F}_{\mathrm{ST}}=-0.002, \mathrm{p}=0.883\right)$. The two methods used to identify the optimal K from the STRUCTURE analyses differed in their results. The Evanno method indicated $\mathrm{K}=2$, which was consistent with STUCTURE bar plots generated from the locprior runs that indicated a NC cluster and a NH/NWT cluster (Fig. 2). However, structure was not apparent in the bar plot for $\mathrm{K}=2$ for the model runs that did not include sampling locations as a prior. The ln-likelihood method suggested all samples belonged to a single cluster, irrespective of whether sampling location was included as a prior.

Fig. 2. STRUCTURE output using the Evanno method (Evanno et al. 2005) and STRUCTURE HARVESTER (Earl and vonHoldt 2012) with (A) sampling locations as a prior and (B) without sampling locations as a prior. Sample sites are indicated on the X axis. NC: Coweeta, North Carolina, USA; NH: Canaan, New Hampshire, USA; NWT: Fort Liard, Northwest Territories, Canada.
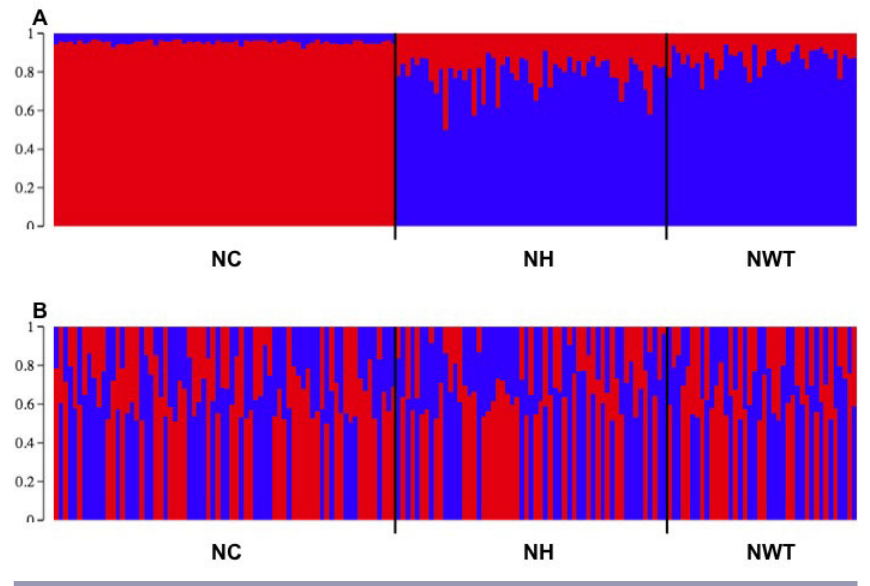

\section{DISCUSSION}

An understanding of genetic diversity and structure is essential for the development of science-based conservation and management strategies for species threatened by habitat loss and climate change. Studies suggest that although neutral genetic diversity may not be correlated with adaptive genetic diversity, neutral genetic variation is an important consideration in conservation (Bonin et al. 2007, Moritz 1994) and molecular markers are effective tools for investigating gene flow, migration, and dispersal among populations (Holderegger et al. 2006).

Consistent with our hypotheses, we found evidence of possible population structure, with the southern trailing-edge population (North Carolina) being genetically distinct from the central (New Hampshire) and leading-edge (Northwest Territories) populations. In contrast to our predictions, the central and leading-edge populations did not differ from one another in spite of the large geographic distance between them. The Northwest Territories population did, however, have fewer unique alleles, consistent with a more recently established population.

Subtle genetic structure was present among the sampled Canada Warbler populations. Pairwise $\mathrm{F}_{\mathrm{ST}}$ estimates indicated low but significant differentiation between $\mathrm{NC}$ and the two other populations ( $\mathrm{F}_{\mathrm{ST}}=0.008, \mathrm{p}<0.0001$ for both comparisons). The Evanno method interpretation of STRUCTURE analyses using sampling locations as a prior (locprior) also supported the presence of two gene pools $(K=2)$, with individuals sampled in North Carolina assigned to one cluster, and individuals from NWT and NH assigned to a second cluster (Fig. 2). Without using 
Avian Conservation and Ecology 13(1): 8

http://www.ace-eco.org/vol13/iss1/art8/

sampling location as a prior (nolocprior), the Evanno method interpretation of STRUCTURE analysis did not support $\mathrm{K}=2$. Analyses using the ln-likelihood method indicated the presence of a single gene pool.

This study suggests the possibility that the southern trailing-edge population of Canada Warblers may be genetically distinct from central and leading-edge populations and harbor unique genetic diversity. Although more comprehensive sample coverage and analyses are needed, these observations raise the possibility that extirpation of populations in the southern range margin could have negative genetic consequences for the species overall. Climate-based distribution modeling predicts range shifts for 15 boreal bird species under two carbon emissions scenarios (Ralston and Kirchman 2013) and other models predict poleward and upslope shifts with declines or extirpation of high elevation bird populations (Rodenhouse et al. 2007, Virkkala et al. 2008). Trailing-edge populations of Canada Warblers already occur at the highest elevations in much of the southern Appalachians, so shifts in elevation are not possible. Species can persist in new conditions brought on by climate change through adaptation (Hoffmann and Sgrò 2011) or shifting their range (Chen et al. 2011). However, if the environment is changing more rapidly than the species can respond with adaption or range shifts, this may lead to extirpation (Davis and Shaw 2001, Dawson et al. 2011, Stralberg et al. 2015). This may also be the case for much of the biodiversity found in the southern Appalachian Mountains, which represents the low latitude range limit of numerous taxa (Stein et al. 2000).

Trailing-edge populations of Canada Warblers may be genetically distinct from populations at higher latitudes in the central and leading-edge of the species' range, and harbor unique genetic diversity. However, more comprehensive sampling throughout the breeding range is needed to gain a more complete understanding of the spatial distribution of genetic diversity. Future studies should also attempt to understand the extent to which divergence of southern Appalachian populations is adaptive or the result of drift (Weeks et al. 2016).

Responses to this article can be read online at: http://www.ace-eco.org/issues/responses.php/1176

\section{Acknowledgments:}

The authors gratefully acknowledge research funding provided by the University of Georgia Warnell School of Forestry and Natural Resources and resources available at the Georgia Genomics Facility. We thank Samuel Merker for assisting with data collection in North Carolina. We thank Rhiannon Pankratz and Rick Ludkin for sample collections in Canada and Environment and Climate Change Canada for funds supporting those collections. We thank $P$. Benham, M. Hallworth, M. Goodnow, A. Kimiatek, J. Wampler, M. Martin, C. Burns, and A. Demko for assistance in data collection from New Hampshire. We thank the Town of Canaan, N.H. and the Mascoma Watershed Conservation Council for permission to use the study sites. We thank Plymouth State University and the New England Institute for Landscape Ecology for funding. We gratefully acknowledge permission for use of the Canada Warbler range map in Figure 1 from The Birds of North America https:// birdsna.org, maintained by the Cornell Lab of Ornithology.

\section{LITERATURE CITED}

Arenas, M., N. Ray, M. Currat, and L. Excoffier. 2012. Consequences of range contractions and range shifts on molecular diversity. Molecular Biology and Evolution 29:207-218. http://dx.doi.org/10.1093/molbev/msr187

Ball, J., P. Sólymos, F. Schmiegelow, S. Hache, J. Schieck, and E. Bayne. 2016. Regional habitat needs of a nationally listed species, Canada Warbler (Cardellina canadensis), in Alberta, Canada. Avian Conservation and Ecology 11(2):10. http://dx.doi. org/10.5751/ACE-00916-110210

Becker, D. A., P. B. Wood, and P. D. Keyser. 2012. Canada Warbler use of harvested stands following timber management in the southern portion of their range. Forest Ecology and Management 276:1-9. http://dx.doi.org/10.1016/j.foreco.2012.03.018

Bohonak, A. J. 1999. Dispersal, gene flow, and population structure. Quarterly Review of Biology 74:21-45. http://dx.doi. org/10.1086/392950

Bonin, A., F. Nicole, F. Pompanon, C. Miaud, and P. Taberlet. 2007. Population adaptive index: a new method to help measure intraspecific genetic diversity and prioritize populations for conservation. Conservation Biology 21(3):697-708. http://dx.doi. org/10.1111/j.1523-1739.2007.00685.x

Chen, I., J. K. Hill, R. Ohlemüller, D. B. Roy, and C. D. Thomas. 2011. Rapid range shifts of species of climate warming. Science 333:1024-1026. http://dx.doi.org/10.1126/science.1206432

Cobben, M. M. P., J. Verboom, P. F. M. Opdam, R. F. Hoekstra, R. Jochem, P. Arens, and M. J. M. Smulders. 2011. Projected climate change causes loss and redistribution of genetic diversity in a model metapopulation of a medium-good disperser. Ecography 34:920-932. http://dx.doi.org/10.1111/j.1600-0587.2011.06713. $\mathrm{x}$

Committee on the Status of Endangered Wildlife in Canada (COSEWIC). 2008. COSEWIC assessment and status report on the Canada Warbler in Canada. COSEWIC, Ottawa, Ontario, Canada. http://www.sararegistry.gc.ca/default.asp?lang= En\&n=9C5EFEF4-1

Coulon, A., J. W. Fitzpatrick, R. Bowman, B. M. Stith, C. A. Makarewich, L. M. Stenzler, and I. J. Lovette. 2008. Congruent population structure inferred from dispersal behaviour and intensive genetic surveys of the threatened Florida scrub-jay (Aphelocoma coerulescens). Molecular Ecology 17:1685-1701. http://dx.doi.org/10.1111/j.1365-294X.2008.03705.x

Crandall, K. A., O. R. P. Bininda-Emonds, G. M. Mace, and R. K. Wayne. 2000. Considering evolutionary processes in conservation biology. Trends in Ecology and Evolution 15:290-295. http://dx.doi.org/10.1016/S0169-5347(00)01876-0

Davis, M. B., and R. G. Shaw. 2001. Range shifts and adaptive responses to quaternary climate change. Science 292:673-679. http://dx.doi.org/10.1126/science.292.5517.673 
Dawson, T. P., S. T. Jackson, J. I. House, I. C. Prentice, and G. M. Mace. 2011. Beyond predictions: biodiversity conservation in a changing climate. Science 332:53-58. http://dx.doi.org/10.1126/ science. 1200303

Earl, D. A., and B. M. vonHoldt. 2012. STRUCTURE HARVESTER: a website and program for visualizing STRUCTURE output and implementing the Evanno method. Conservation Genetics Resources 4:359-361. http://dx.doi. org/10.1007/s12686-011-9548-7

Eckert, C. G., K. E. Samis, and S. C. Lougheed. 2008. Genetic variation across species' geographical ranges: the centralmarginal hypothesis and beyond. Molecular Ecology 17:1170-1188. http://dx.doi.org/10.1111/j.1365-294X.2007.03659. $\mathrm{x}$

Environment Canada. 2016. Recovery strategy for the Canada Warbler (Cardellina canadensis) in Canada. Species at Risk Act Recovery Strategy Series. Environment Canada, Ottawa, Ontario, Canada.

Evanno, G., S. Regnaut, and J. Goudet. 2005. Detecting the number of clusters of individuals using the software structure: a simulation study. Molecular Ecology 14:2611-2620. http://dx.doi. org/10.1111/j.1365-294X.2005.02553.x

Excoffier, L., G. Laval, and S. Schneider. 2005. Arlequin (version 3.0): an integrated software package for population genetics data analysis. Evolutionary Bioinformatics 1:47-50. http://dx.doi. org/10.1177/117693430500100003

Faircloth, B. C. 2006. GMCONVERT: file conversion for GENEMAPPER output files. Molecular Ecology Resources 6:968-970. http://dx.doi.org/10.1111/j.1471-8286.2006.01419.x

Faircloth, B. C. 2008. MSATCOMMANDER: Detection of microsatellite repeat arrays and automated, locus-specific primer design. Molecular Ecology Resources 8:92-94. http://dx.doi. org/10.1111/j.1471-8286.2007.01884.x

Frankham, R. 2005. Genetics and extinction. Biological Conservation 126:131-140. http://dx.doi.org/10.1016/j.biocon.2005.05.002

Fraser, D. J., and L. Bernatchez. 2001. Adaptive evolutionary conservation: towards a unified concept for defining conservation units. Molecular Ecology 10:2741-2752.

Goodnow, M. L., and L. R. Reitsma. 2011. Nest site selection of Canada Warblers (Wilsonia canadensis) in central New Hampshire. Canadian Journal of Zoology 89:1172-1177. http:// dx.doi.org/10.1139/z11-094

Haché, S., P. Solymos, T. Fontaine, E. Bayne, S. Cumming, F. Schmiegelow, and D. Stralberg. 2014. Analyses to support critical habitat identification for Canada Warbler, Olive-sided Flycatcher, and Common Nighthawk. Technical Report for Environment Canada. Boreal Avian Modelling Project, Edmonton, Alberta, Canada.

Hallworth, M., A. Ueland, E. Anderson, J. D. Lambert, and L. Reitsma. 2008. Habitat selection and site fidelity in Canada Warblers (Wilsonia canadensis) in Central New Hampshire. Auk 125:880-888. http://dx.doi.org/10.1525/auk.2008.07115
Hampe, A., and R. J. Petit. 2005. Conserving biodiversity under climate change: the rear edge matters. Ecology Letters 8:461-467. http://dx.doi.org/10.1111/j.1461-0248.2005.00739.x

Hewitt, G. M. 1996. Some genetic consequences of ice ages, and their role in divergence and speciation. Biological Journal of the Linnean Society 58:247-276. http://dx.doi.org/10.1111/j.1095-8312.1996. tb01434.x

Hewitt, G. M. 2004. Genetic consequences of climatic oscillations in the Quaternary. Philosophical Transactions of the Royal Society B: Biological Sciences 359:183-195. http://dx.doi.org/10.1098/ rstb.2003.1388

Hoffmann, A. A., and C. M. Sgrò. 2011. Climate change and evolutionary adaptation. Nature 470:479-485. http://dx.doi. org/10.1038/nature09670

Holderegger, R., U. Kamm, and F. Gugerli. 2006. Adaptive vs. neutral genetic diversity: implications for landscape genetics. Landscape Ecology 21:797-807. http://dx.doi.org/10.1007/ s10980-005-5245-9

Hughes, J. B., G. C. Daily, and P. R. Ehrlich. 1997. Population diversity: its extent and extinction. Science 278:689-692. http:// dx.doi.org/10.1126/science.278.5338.689

Kalinowski, S. T., M. L. Taper, and T. C. Marshall. 2007. Revising how the computer program CERVUS accommodates genotyping error increases success in paternity assignment. Molecular Ecology 16:1099-1106. http://dx.doi.org/10.1111/j.1365-294X.2007.03089. $\mathrm{x}$

Kamvar, Z. N., J. F. Tabima, and N. J. G. Grünwald. 2014. Poppr: an $\mathrm{R}$ package for genetic analysis of populations with clonal, partially clonal, and/or sexual reproduction. PeerJ 2:e281. http:// dx.doi.org/10.7717/peerj.281

Kearse, M., R. Moir, A. Wilson, S. Stones-Havas, M. Cheung, S. Sturrock, S. Buxton, A. Cooper, S. Markowitz, C. Duran, T. Thierer, B. Ashton, P. Meintjes, and A. Drummond. 2012. Geneious basic: an integrated and extendable desktop software platform for the organization and analysis of sequence data. Bioinformatics 28:1647-1649. http://dx.doi.org/10.1093/bioinformatics/ bts199

Keenan, K., P. McGinnity, T. F. Cross, W. W. Crozier, and P. A. Prodöhl. 2013. diveRsity: an R package for the estimation of population genetics parameters and their associated errors. Methods in Ecology and Evolution 4:782-788. http://dx.doi. org/10.1111/2041-210X.12067

Langham, G. M., J. G. Schuetz, T. Distler, C. U. Soykan, and C. Wilsey. 2015. Conservation status of North American birds in the face of future climate change. PLOS ONE 10:e0135350. http://dx. doi.org/10.1371/journal.pone.0135350

Mason, S. C., G. Palmer, R. Fox, S. Gillings, J. K. Hill, C. D. Thomas, and T. H. Oliver. 2015. Geographical range margins of many taxonomic groups continue to shift polewards. Biological Journal of the Linnean Society 115:586-597. http://dx.doi. org/10.1111/bij.12574

Matthews, S., R. O’Connor, L. R. Iverson, and A. M. Prasad. 2004. Atlas of climate change effects in 150 bird species of the 
Eastern United States. General Technical Report NE-318. U.S. Department of Agriculture, Forest Service, Northeastern Research Station, Newtown Square, Pennsylvania, USA.

McInerny, G. J., J. R. G. Turner, H. Y. Wong, J. M. J. Travis, and T. G. Benton. 2009. How range shifts induced by climate change affect neutral evolution. Proceedings of the Royal Society $B$ 276:1527-1534. http://dx.doi.org/10.1098/rspb.2008.1567

Moritz, C. 1994. Defining 'evolutionarily significant units' for conservation. Trends in Ecology and Evolution 9:373-375. http:// dx.doi.org/10.1016/0169-5347(94)90057-4

Parisod, C., and S. Joost. 2010. Divergent selection in trailingversus leading-edge populations of Biscutella laevigata. Annals of Botany 105:655-660. http://dx.doi.org/10.1093/aob/mcq014

Parmesan, C. 2006. Ecological and evolutionary responses to recent climate change. Annual Review of Ecology, Evolution and Systematics 37:637-669. http://dx.doi.org/10.1146/annurev. ecolsys.37.091305.110100

Pauls, S. U., C. Nowak, M. Bálint, and M. Pfenninger. 2013. The impact of global climate change on genetic diversity within populations and species. Molecular Ecology 22:925-946. http:// dx.doi.org/10.1111/mec. 12152

Petit, R. J., I. Aguinagalde, J.-L. de Beaulieu, C. Bittkau, S. Brewer, R. Cheddadi, R. Ennos, S. Fineschi, D. Grivet, M. Lascoux, A. Mohanty, G. Muller-Starck, B. Demesure-Musch, A. Palme, J. P. Martin, S. Rendell, and G. G. Vendramin. 2003. Glacial refugia: hotspots but not melting pots of genetic diversity. Science 300:1563-1565. http://dx.doi.org/10.1126/science.1083264

Pritchard, J. K., M. Stephens, and P. Donnelly. 2000. Inference of population structure using multilocus genotype data. Genetics 155:945-959.

Provan, J., and C. A. Maggs. 2012. Unique genetic variation at a species' rear edge is under threat from global climate change. Proceedings of the Royal Society B 279:39-47. http://dx.doi. org/10.1098/rspb.2011.0536

R Core Team. 2016. R: a language and environment for statistical computing. R Foundation for Statistical Computing, Vienna, Austria.

Ralston, J., and J. J. Kirchman. 2013. Predicted range shifts in North American boreal forest birds and the effect of climate change on genetic diversity in Blackpoll Warblers (Setophaga striata). Conservation Genetics 14:543-555. http://dx.doi. org/10.1007/s10592-012-0418-y

Raymond, M., and F. Rousset. 1995. GENEPOP (Version 1.2): Population genetics software for exact tests and ecumenicism. Journal of Heredity 86:248-249. http://dx.doi.org/10.1093/ oxfordjournals.jhered.a111573

Reitsma, L., M. Goodnow, M. T. Hallworth, and C. J. Conway. 2010. Canada Warbler (Cardellina canadensis). In P. G. Rodewald, editor. The birds of North America. Cornell Lab of Ornithology, Ithaca, New York, USA. [online] URL: https:// birdsna.org/Species-Account/bna/species/canwar/introduction

Rodenhouse, N. L., S. N. Matthews, K. P. Mcfarland, J. D. Lambert, L. R. Iverson, A. Prasad, T. S. Sillett, and R. T. Holmes.
2007. Potential effects of climate change on birds of the northeast. Mitigation and Adaptation Strategies for Global Change 13:517-540. http://dx.doi.org/10.1007/s11027-007-9126-1

Rosenberg, N. A., T. Burke, K. Elo, M. W. Feldman, P. J. Freidlin, M. A. M. Groenen, J. Hillel, A. Maki-Tanila, M. Tixier-Boichard, A. Vignal, K. Wimmers, and S. Weigend. 2001. Empirical evaluation of genetic clustering methods using multilocus genotypes from 20 chicken breeds. Genetics 159:699-713.

Sauer, J. R., J. E. Hines, J. E. Fallon, K. L. Pardieck, D. J. Ziolkowski, Jr., and W. A. Link. 2014. The North American breeding bird survey, results and analysis 1966-2013. Version 01.30.2015. U.S. Geological Survey Patuxent Wildlife Research Center, Laurel, Maryland, USA.

Stein, B. A., L. S. Kutner, and J. S. Adams. 2000. Biodiversity: our precious heritage. Pages 119-158 in B. A. Stein, L. S. Kutner, and J. S. Adams, editors. Precious heritage: the status of biodiversity in the United States. The Nature Conservancy and Association for Biodiversity Information. Oxford University Press, New York, New York, USA.

Stralberg, D., S. M. Matsuoka, A. Hamann, E. M. Bayne, P. Sólymos, F. K. A. Schmiegelow, X. Wang, S. G. Cumming, and S. J. Song. 2015. Projecting boreal bird responses to climate change: the signal exceeds the noise. Ecological Applications 25:52-69. http://dx.doi.org/10.1890/13-2289.1

Stralberg, D., S. M. Matsuoka, C. M. Handel, F. K. A. Schmiegelow, A. Hamann, and E. M. Bayne. 2017. Biogeography of boreal passerine range dynamics in western North America: past, present, and future. Ecography 40:1050-1066 http://dx.doi. org/10.1111/ecog.02393

Temple, H. J., J. I. Hoffman, and W. Amos. 2006. Dispersal, philopatry and intergroup relatedness: fine-scale genetic structure in the White-breasted Thrasher, Ramphocinclus brachyurus. Molecular Ecology 15:3449-3458. http://dx.doi.org/10.1111/ j.1365-294X.2006.03006.x

Tumas, H. R., B. M. Shamblin, M. S. Woodrey, and C. J. Nairn. 2017. Microsatellite markers for population studies of the salt marsh species Juncus roemerianus (Juncaceae). Applications in Plant Sciences 5(3):1600141. http://dx.doi.org/10.3732/apps. 1600141

Tzedakis, P., I. T. Lawson, M. R. Frogley, G. M. Hewitt, and R. C. Preece. 2002. Buffered tree population changes in a Quaternary refugium: evolutionary implications. Science 297:2044-2047. http://dx.doi.org/10.1126/science.1073083

Virkkala, R., R. K. Heikkinen, N. Leikola, and M. Luoto. 2008. Projected large-scale range reductions of northern-boreal land bird species due to climate change. Biological Conservation 141:1343-1353. http://dx.doi.org/10.1016/j.biocon.2008.03.007

Vucetich, J. A., and T. A. Waite. 2003. Spatial patterns of demography and genetic processes across the species' range: null hypotheses for landscape conservation genetics. Conservation Genetics 4:639-645. http://dx.doi.org/10.1023/A:1025671831349

Walsh, J., A. I. Kovach, K. J. Babbitt, and K. M. O. Brien. 2012. Fine-scale population structure and asymmetrical dispersal in an obligate salt-marsh passerine, the Saltmarsh Sparrow (Ammodramus caudacutus). Auk 129:247-258. http://dx.doi. org/10.1525/auk.2012.11153 
Weeks, A. R., J. Stoklosa, and A. A. Hoffmann. 2016. Conservation of genetic uniqueness of populations may increase extinction likelihood of endangered species: the case of Australian mammals. Frontiers in Zoology 13:31. http://dx.doi. org/10.1186/s12983-016-0163-Z

Zuckerberg, B., A. M. Woods, and W. F. Porter. 2009. Poleward shifts in breeding bird distributions in New York State. Global Change Biology 15:1866-1883. http://dx.doi.org/10.1111/

j.1365-2486.2009.01878.x 